\title{
ОСОБЛИВОСТІ ПОРУШЕНЬ ВУГЛЕВОДНОГО ТА ЛІПІДНОГО МЕТАБОЛІЗМУ У ХВОРИХ НА ГОСТРИЙ ІНФАРКТ МІОКАРДА 3 НОРМАЛЬНОЮ І ПІДВИЩЕНОЮ МАСОЮ ТІЛА
}

Вступ. За розповсюдженістю та несприятливими наслідками гострий інфраркт міокарда (IM) залишається однією з актуальних проблем кардіології протягом багатьох років.

Мета дослідження - провести порівняльний аналіз показників метаболізму вуглеводного та ліпідного обміну у хворих на інфраркт міокарда з нормальним і підвищеним індексом маси тіла та осіб з метаболічним синдромом.

Mетоди дослідження. У дослідження було включено 77 чоловіків, хворих на гострий ІМ з елевацією сегмента ST. У всіх пацієнтів визначали масу тіла (кг), зріст (м), індекс маси тіла (IMT, кг/м²), окружність талії (ОT, см) і окружність стегон (ОС, см), відношення ОТ/ОС. За IMT хворих поділили на 3 групи: нор-

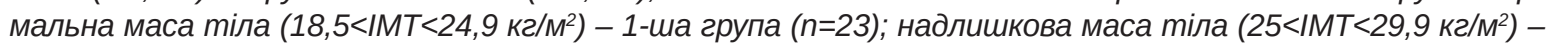
2-га група ( $n=33) ;$ ожиріння (IMT>30 кг/M²) - 3-тя група (n=21). Під час біохімічного дослідження визначали рівні кардіальних тропонінів I та Т, МВ-фрракції креатинфоссрокінази (КФК-МВ), ліпідного спектра крові, глікемії і концентрації інсуліну у вихідному стані, натще після 8-годинного голодування та на 12-ту добу. Одночасно у хворих визначали також постпрандіальні рівні глікемії, а при необхідності проводили тест на толерантність до вуглеводів за загальноприйнятою методикою. Статистичну обробку отриманих результатів виконували за допомогою пакета статистичних програм Statistica 10.0 та програми Microsoft Exel-2013.

Результати й обговорення. У вихідному стані в більшості пацієнтів усіх досліджуваних груп показники ОТ і ОТ/ОС перевищували верхню межу гендерної норми: в 1-й групі - у 69,5 \% (n=16), у 2-й - у 81,8 \% (n=27), в 3-й - у 85,7 \% (n=18) хворих $(p<0,05)$, що свідчить про дисметаболічні порушення в організмі не лише хворих з надлишковою масою тіла та ожирінням, але й пацієнтів з нормальною масою тіла. Одночасно в цих пацієнтів діагностували гіперглікемію, гіперінсулінемію та атерогенну дисліпопротеїнемію.

Висновок. Розвиток інсулінорезистентності й метаболічного синдрому у хворих на ІМ супроводжується значущими порушеннями вуглеводного і ліпідного обміну, що проявляється гіперглікемією, гіперінсулінемією та атерогенною дисліпідемією в гострий і підгострий періоди хвороби у пацієнтів з вісцеральним ожирінням незалежно від маси тіла.

КЛЮЧОВІ СЛОВА: інфраркт міокарда; надмірна маса тіла; ожиріння; інсулінорезистентність; вісцеральний жир; вуглеводний обмін; ліпідний обмін.

ВСТУП. За розповсюдженістю та несприятливими наслідками гострий інфраркт міокарда (IM) залишається однією з актуальних проблем кардіології протягом багатьох років [1]. Упровадження сучасних технологій діагностики, лікування і реабілітації сприяло суттєвому зниженню летальності цієї категорії хворих. Проте несвоєчасне проведення реперфузійної терапії або наявність супутньої патології (ожиріння, цукровий діабет, артеріальна гіпертензія, подагра) ускладнює своєчасну діагностику гострого коронарного синдрому та значно погіршує результати лікування даної коморбідної патології [2]. Серед провідних фракторів ризику розвитку IM (с) М. І. Швед, І. О. Ястремська, 2021. важливу роль відводять абдомінальному ожирінню [3], яке, на думку експертів ВООЗ, набуває епідемічного поширення в усьому світі $[4,5]$. Тому при збереженні темпів зростання кількості людей 3 надмірною масою тіла з'являється реальна загроза збільшення і поширеності IM у сучасній популяції. Водночас питання про наявність причинно-наслідкових зв'язків між фрормуванням абдомінального ожиріння, інсулінорезистентності (IP), цукрового діабету 2 типу, дисліпідемії та розвитком і прогресуванням серцево-судинних захворювань залишається відкритим.

Сукупність зазначених станів об'єднується поняттям "метаболічний синдром" [3]. При цьому ряд авторів вважає, що ключову роль у розвитку 
метаболічного синдрому відіграє інсулінорезистентність [6]. На думку інших дослідників [7], абдомінальне ожиріння не завжди супроводжується IP i, навпаки, може бути в осіб з нормальною масою тіла.

Вищенаведені фракти стали обґрунтуванням для проведення цього дослідження.

Мета дослідження - провести порівняльний аналіз показників метаболізму вуглеводного та ліпідного обміну у хворих на інфраркт міокарда з нормальним і підвищеним індексом маси тіла та осіб з метаболічним синдромом.

МЕТОДИ ДОСЛІДЖЕННЯ. У дослідження було включено 77 чоловіків, хворих на гострий інфраркт міокарда з елевацією сегмента ST. Їх вік становив $(57,54 \pm 8,02)$ року. Всі хворі отримували стандартне лікування відповідно до протоколів МОЗ України [8].

У всіх пацієнтів визначали масу тіла (кг), зріст (м), індекс маси тіла (IMT, кг/M²), окружність талії (ОТ, см) і окружність стегон (ОС, см), відношення ОТ/ОС. За ІМТ хворих поділили на 3 групи: нормальна маса тіла $\left(18,5<\mathrm{IMT}<24,9 \mathrm{kr} / \mathrm{M}^{2}\right)-$ 1-ша група $(n=23) ;$ надлишкова маса тіла $\left(25<\mathrm{IMT}<29,9 \mathrm{kr} / \mathrm{M}^{2}\right)$ - 2-га група ( $\left.\mathrm{n}=33\right)$; ожиріння $\left(\mathrm{IMT}>30 \mathrm{kr} / \mathrm{M}^{2}\right)$ - 3-тя група $(\mathrm{n}=21)$.

Діагноз гострого IM верифрікували згідно 3 рекомендаціями ESC [2] при наявності типового ангінозного нападу, динаміки специфрічних змін кривої електрокардіограми (реципрокне зміщення сегмента ST) та ознак резорбтивно-некротичного синдрому. Підтверджували діагноз за допомогою лабораторних та інструментальних методів обстеження. Досліджували показники загального аналізу крові та визначали рівні кардіальних тропонінів I та T, MB-фрракції креатинсросфрокінази (КФК-МВ), використовуючи автоматичний біохімічний аналізатор "Cobas integra 400 plus" форми "Roche" (Швейцарія). Кількісне визначення тропоніну Т проводили за допомогою електрохемілюмінісцентного біохімічного аналізатора "Elecsys 2010" фірми "Roche Hitachi" (Швейцарія).

Кров на аналізи для вимірювання ліпідного спектра крові (загального холестерину (3ХC), холестерину ліпопротеїнів високої щільності
(ХС ЛПВЩ), холестерину ліпопротеїнів низької щільності (ХС ЛПНЩ) і триацилгліцеролів (ТГ)) брали натще після 8-годинного голодування та на 12-ту добу. Рівень глюкози у крові натще визначали теж на 12-ту добу після прийняття хворого в стаціонар, оскільки гострий метаболічний стрес через гострий коронарний синдром може впливати на рівні глюкози і ліпідів у плазмі крові. Одночасно у пацієнтів з IM визначали також постпрандіальні рівні глікемії та концентрацію інсуліну, а при необхідності проводили тест на толерантність до вуглеводів за загальноприйнятою методикою [9]. Для виключення цукрового діабету в день госпіталізації визначали рівень глікованого гемоглобіну (HbA1c) та інсулінорезистентність за допомогою індексу НОМА.

Статистичну обробку отриманих результатів виконували за допомогою пакета статистичних програм Statistica 10.0 та програми Microsoft Exel-2013.

РЕЗУЛЬТАТИ Й ОБГОВОРЕННЯ. У вИХіДНОму стані в більшості пацієнтів усіх досліджуваних груп показники ОТ і ОТ/ОС перевищували верхню межу гендерної норми: в 1-й групі - у 69,5 \% $(n=16)$, у $2-и ̆-$ y $81,8 \%(n=27)$, в 3-й - у $85,7 \%$ $(n=18)$ хворих $(p<0,05)$. Наведені катамнестичні результати можуть свідчити про дисметаболічні порушення в організмі не лише хворих 3 надлишковою масою тіла та ожирінням, але й пацієнтів з нормальною масою тіла (табл. 1). Отримані дані узгоджуються 3 думкою дослідників щодо можливості розвитку метаболічного синдрому і в осіб з нормальною масою тіла [10].

У вихідному стані (при прийнятті в стаціонар) у більшості пацієнтів зареєстровано гіперглікемію натще: в 1-й групі - у 82,6 \% (n=19), у 2-й -y $78,8 \%(n=26)$, у $3-и ̆-$ у $81 \%(n=17)$ хворих $(p<0,05)$ (табл. 2), тоді як рівень глікованого гемоглобіну не перевищував норми в жодного хворого. Отримані дані дозволили виключити в обстежених пацієнтів наявність цукрового діабету до розвитку IM, а виявлена транзиторна гіперглікемія в гострий період IM (гострий коронарний синдром), на думку науковців, зумовлена активацією симпатоадреналової системи, підвище-

Таблиця 1 - Показники окружності талії та стегон у хворих на інфаркт міокарда з різною масою тіла

\begin{tabular}{||l|c|c|c|c|c|c||}
\hline \multicolumn{1}{|c|}{ Показник } & $\begin{array}{c}\text { 1-ша група } \\
(\mathrm{n}=23)\end{array}$ & $\begin{array}{c}\text { 2-га група } \\
(\mathrm{n}=33)\end{array}$ & $\begin{array}{c}\text { 3-тя група } \\
(\mathrm{n}=21)\end{array}$ & $\mathrm{P}_{1-2}$ & $\mathrm{P}_{1-3}$ & $\mathrm{P}_{2-3}$ \\
\hline $\mathrm{OT}, \mathrm{cm}$ & $94,2(84,0-97,0)$ & $104,0(101,0-109,0)$ & $123,2(110,0-124,0)$ & $\mathrm{p}<0,05$ & $\mathrm{p}<0,05$ & $\mathrm{p}<0,05$ \\
\hline $\mathrm{OC}, \mathrm{CM}$ & $96,0(92,5-98,0)$ & $100,0(98,0-104,0)$ & $115,6(101,0-121,0)$ & $\mathrm{p}<0,05$ & $\mathrm{p}<0,05$ & $\mathrm{p}<0,05$ \\
\hline OT/OC & $0,97(0,8-1,1)$ & $1,03(0,7-1,2)$ & $1,14(1,0-1,2)$ & $\mathrm{p}<0,05$ & $\mathrm{p}<0,05$ & $\mathrm{p}<0,05$ \\
\hline
\end{tabular}

Примітки. Тут і в таблицях 2, 3:

1. Різницю достовірності між групами визначали за критерієм $\chi^{2}$-Пірсона.

2. $\mathrm{P}_{1-2}$ - достовірність різниці між 1-ю та 2-ю групами; $\mathrm{P}_{1-3}-$ достовірність різниці між 1-ю і 3-ю групами; $\mathrm{P}_{2-3}-$ достовірність різниці між 2-ю та 3-ю групами обстежених. 
Таблиця 2 - Показники глікемії та інсулінорезистентності у хворих на інфраркт міокарда з нормальним і підвищеним індексом маси тіла

\begin{tabular}{|c|c|c|c|c|c|c|}
\hline Показник & $\begin{array}{c}\text { 1-ша група } \\
(n=23)\end{array}$ & $\begin{array}{c}\text { 2-га група } \\
(n=33)\end{array}$ & $\begin{array}{l}\text { 3-тя група } \\
(\mathrm{n}=21)\end{array}$ & $P_{1-2}$ & $P_{1-3}$ & $P_{2-3}$ \\
\hline HbA1c, \% & $5,3(4,0-5,7)$ & $5,3(4,5-5,9)$ & $5,6(4,3-5,7)$ & $p>0,05$ & $p>0,05$ & $p>0,05$ \\
\hline Глюкоза на 1-шу добу, ммоль/л & $6,5(5,4-7,7)$ & $6,6(5,8-8,0)$ & $6,9(5,8-8,7)$ & $p>0,05$ & $p>0,05$ & $p>0,05$ \\
\hline $\begin{array}{l}\text { Глюкоза на 12-ту добу, } \\
\text { ммоль/л }\end{array}$ & $5,4(5,2-7,6)$ & $6,0(5,6-7,2)$ & $7,6(5,7-10,8)$ & $p<0,05$ & $p<0,05$ & $p<0,05$ \\
\hline $\begin{array}{l}\text { Постпрандіальний рівень } \\
\text { глюкози на 12-ту добу, ммоль/л }\end{array}$ & $5,8(4,8-6,4)$ & $6,2(4,9-6,0)$ & $7,8(5,9-9,7)$ & $p>0,05$ & $p<0,05$ & $p<0,05$ \\
\hline Індекс НОМА, 1-ша доба & $\begin{array}{c}2,41 \\
(0,84-4,95)\end{array}$ & $\begin{array}{c}3,97 \\
(2,01-5,39)\end{array}$ & $\begin{array}{c}4,45 \\
(2,94-9,90)\end{array}$ & $p<0,05$ & $p<0,05$ & $p>0,05$ \\
\hline Індекс НОМА, 12-та доба & $\begin{array}{c}1,20 \\
(1,81-6,71)\end{array}$ & $\begin{array}{c}1,80 \\
(0,62-8,22)\end{array}$ & $\begin{array}{c}3,96 \\
(2,30-8,33)\end{array}$ & $p>0,05$ & $p<0,05$ & $p<0,05$ \\
\hline
\end{tabular}

ним викидом катехоламінів і кортизолу, посиленням процесів глюконеогенезу, глікогенолізу та ліполізу [11]. 3 огляду на те, що до періоду рубцювання зони некрозу активність симпатоадреналової системи знижується, слід було очікувати відновлення показників вуглеводного обміну. Однак, згідно з отриманими даними та на 12-ту добу перебігу IM, у понад половини хворих було зареєстровано підвищення глікемії як натще (в 1-й групі - у 60,8 \% (n=14), у 2-й - у 63,6\% (n=23), у 3-й -у 71,4\% (n=15) пацієнтів, $p<0,05)$, так і через 2 год після їди (в 1-й групі - у 21,7 \% (n=5), у 2-й -у 18,2\% (n=6), у 3-й -у 19,0\% (n=4) хворих, p<0,05). Виявлені зміни вуглеводного обміну у хворих із гострим стресом, зумовленим IM, на тлі накопичення вісцерального жиру свідчать про зрив компенсаторних механізмів у регуляції порушеного вуглеводного обміну і в подальшому можуть слугувати тригером для фрормування IP, гіперсрункції $\beta$-клітин острівкового апарату підшлункової залози та можливого ïx апоптозу [12].

Результати дослідження концентрації інсуліну в плазмі крові підтвердили ці припущення. Так, на 1-шу добу IM глікемію натще зареєстровано: в 1-й групі - у 17,4 \% (n=4), у 2-й - у 15,2 \% $(n=5)$, у 3-й - у 23,8 \% (n=5). На 12-ту добу IM у жодній групі пацієнтів суттєвої динаміки рівня інсуліну в плазмі крові натще не виявлено. Після стандартного сніданку глікемія траплялася значно частіше - майже у кожного четвертого хворого, в тому числі в 1-й групі - у 26,1 \% (n=6), у 2-й - у 24,2 \% (n=8), у 3-й - у 33,3\% (n=7).

Значна частота глікемії серед хворих на IM була зумовлена IP, що підтверджено значеннями індексу НОМА. Інсулінорезистентність на 1-шу добу діагностовано в 52,2 \% (n=12) хворих 1-ї групи, у 57,6 \% (n=19) пацієнтів 2-ї групи та в $61,9 \%(n=13)$ хворих 3-ї групи (p>0,05). На 12-ту добу в більшості пацієнтів IP зберігалася і становила, відповідно, в 1-й групі 43,5 \% (n=10), у 2-й $-45,5 \%(n=15)$, у 3-й - 52,4 \% (n=11) (p>0,05), що дозволило виключити стрес як єдину причину її виникнення.

Аналіз стану ліпідного обміну свідчив про достовірно виражені порушення в усіх пацієнтів з гострим IM (табл. 3). При цьому зауважимо, що в групах хворих 3 надлишковою масою тіла та ожирінням атерогенна гіперліпідемія (підвищення рівня ЗХС, ТГ та ХC ЛПНЩ на фроні зниженої концентрації ХС ЛПВЩ) була достовірно більш виражена, ніж у групі пацієнтів 3 нормальним IMT $(p<0,05)$. Водночас не виявлено суттєвої різниці в концентрації атерогенних ліпопротеїнів між групами хворих на IM з надлишковою масою тіла та ожирінням ( $>0,05)$.

Таким чином, отримані результати дослідження дозволяють зробити висновок, що вста-

Таблиця 3 - Динаміка показників ліпідного профрілю на 1-шу і 12-ту доби перебігу інфаркту міокарда у хворих з різною масою тіла

\begin{tabular}{|c|c|c|c|c|c|c|c|}
\hline \multicolumn{2}{|c|}{ Показник } & $\begin{array}{c}\text { 1-ша група } \\
(\mathrm{n}=23)\end{array}$ & $\begin{array}{c}\text { 2-га група } \\
(n=33)\end{array}$ & $\begin{array}{c}\text { 3-тя група } \\
\text { (n=21) }\end{array}$ & $P_{1-2}$ & $P_{1-3}$ & $P_{2-3}$ \\
\hline \multirow{2}{*}{$\begin{array}{l}\text { ЗХС, } \\
\text { ммоль/л }\end{array}$} & 1 & $5,6(4,40-6,70)$ & $5,9(4,50-6,90)$ & $6,3(4,60-6,90)$ & $p>0,05$ & $p<0,05$ & $p<0,05$ \\
\hline & 2 & $5,3(4,40-6,30)$ & $5,7(4,50-6,90)$ & $6,0(4,90-7,20)$ & $p<0,05$ & $p<0,05$ & $p<0,05$ \\
\hline \multirow{2}{*}{$\begin{array}{l}\text { ХС ЛПНЩ, } \\
\text { ммоль/л }\end{array}$} & 1 & $2,0(2,10-3,48)$ & $2,5(0,82-1,14)$ & $2,6(0,78-1,37)$ & $p<0,05$ & $p<0,05$ & $p>0,05$ \\
\hline & 2 & $1,9(2,40-4,80)$ & $2,62(1,96-3,34)$ & $2,71(2,61-3,69)$ & $p<0,05$ & $p>0,05$ & $p>0,05$ \\
\hline \multirow{2}{*}{$\begin{array}{l}\text { ХС ЛПВЩ, } \\
\text { ммоль/л }\end{array}$} & 1 & $1,09(0,89-1,21)$ & $0,99(0,82-1,23)$ & $0,86(0,73-1,26)$ & $p>0,05$ & $p>0,05$ & $p>0,05$ \\
\hline & 2 & $1,15(0,88-1,11)$ & $0,98(0,84-1,14)$ & $0,93(0,72-1,21)$ & $p>0,05$ & $p>0,05$ & $p>0,05$ \\
\hline \multirow[t]{2}{*}{ ТГ, ммоль/л } & 1 & $1,17(0,99-2,19)$ & $1,97(0,70-1,25)$ & $1,89(0,71-1,41)$ & $p>0,05$ & $p>0,05$ & $p>0,05$ \\
\hline & 2 & $1,03(1,28-2,75)$ & $1,56(1,40-2,06)$ & $1,91(1,61-2,36)$ & $p<0,05$ & $p<0,05$ & $p>0,05$ \\
\hline
\end{tabular}

Примітка. 1 і 2 - параметри показників на 1-шу і 12-ту доби. 
новлена висока частота гіперінсулінемії і порушень вуглеводного та ліпідного обміну в пацієнтів як з підвищеним, так і з нормальним індексом маси тіла свідчить про те, що досліджувані порушення метаболізму зумовлені не лише збільшенням маси тіла, але й накопиченням вісцерального жиру.

Проведене дослідження також показало, що в більшості хворих на IM з надмірною масою тіла та ожирінням розвивається IP, яка супроводжується порушеннями процесів метаболізму вуглеводів і ліпідів у гострий та підгострий періоди IM.

Отримані результати підтверджують думку багатьох дослідників [13], що накопичення вісцерального жиру має вирішальне значення у фрормуванні компонентів метаболічного синдрому.

ВИСНОВКИ. 1. У хворих на інфраркт міокарда метаболічний синдром діагностують у 65,6 \% пацієнтів з нормальним індексом маси тіла, у 85,7 \% - 3 надмірною масою тіла й у 96,3 \% - 3 ожирінням, що проявляється збільшенням ок-

\section{СПИСОК ЛІТЕРАТУРИ}

1. Gach O. Acute coronary syndrome / O. Gach, Z. Husseini, P. Lancellotti // Rev. Med. Liege. - 2018. 73 (5-6). - P. 243-250.

2. ESC Guidelines for the management of acute myocardial infarction in patients presenting with STsegment elevation: The Task Force on the management of ST-segment elevation acute myocardial infarction of the European Society of Cardiology (ESC). European Heart Journal. - 2012. - 33 (20). - P. 2569-2619.

3. Impact of metabolic syndrome on clinical severity and long-term prognosis in patients with myocardial infarction with ST-segment elevation / M. Lovic, D. Djordjevic, I. Tasic [et al.] // Hellenic Journal of Cardiology. 2018. - 59 (4). - P. 226-231.

4. Kelli H. Cardio metabolic syndrome: A global epidemic / H. Kelli, I. Kassas, O. Lattouf // J Diabetes Metab. - 2015. - 6 (3). - P. 263-275.

5. IDF Diabetes Atlas: global estimates for the prevalence of diabetes for 2015 and 2040 / K. Ogurtsova, J. Fernandes, Y. Huang [et al.] // Diabetes Research and Clinical Practice. - 2017. - 128. - P. 40-50. DOI: 10.1016/j. diabres.2017.03.024.

6. Christopher Nolan J. Insulin resistance and insulin hypersecretion in the metabolic syndrome and type 2 diabetes: Time for a conceptual framework shift / J. Christopher Nolan, M. Prentki // SAGE Jorna. - 2019. 16 (2). - P. 118-127. - Access mode : https://doi. org/10.1177/1479164119827611

7. Sperling L. The cardiometabolic health alliance: working toward a new care model for the metabolic syndrome / L. Sperling, J. Mechanick, I. Neeland // J. Am. Coll. Cardiol. - 2015. - 66 - P. 1050-1067. ружності талії понад 94 см для чоловіків, наявністю інсулінорезистентності, підвищенням глікемії натще понад 5,6 ммоль/л і рівня триацилгліцеролів понад 1,7 ммоль/л, зниженням рівня холестерину ліпопротеїнів високої щільності менше 1,0 ммоль/л, а також підвищенням артеріального тиску понад 130/85 мм рт. ст.

2. Розвиток інсулінорезистентності й метаболічного синдрому у хворих на інфаркт міокарда супроводжується значущими порушеннями вуглеводного та ліпідного обміну, що проявляється гіперглікемією, гіперінсулінемією та атерогенною дисліпідемією в гострий і підгострий періоди хвороби у пацієнтів з вісцеральним ожирінням незалежно від маси тіла.

Перспективи подальших досліджень. Виявлені суттєві порушення вуглеводого і ліпідного обміну у хворих на гострий інфаркт міокарда 3 нормальною та підвищеною масою тіла обґрунтовують доцільність розробки диференційованих адекватних програм корекції як маси тіла, так і метаболічних порушень.
8. Унісрікований клінічний протокол екстреної, первинної, вторинної (спеціалізованої) та третинної (високоспеціалізованої) медичної допомоги та медичної реабілітації хворих на гострий коронарний синдром з елевацією сегмента ST / М. К. Хобзей, Ю. М. Сіренко, А. В. Степаненко [та ін.] // Наказ МОЗ України від 02.07.2014 p. № 455.

9. Камінський О. В. Офріційні критерії діагностики цукрового діабету, нормоглікемія і самоконтроль глікемії // Міжнар. ендокрин. журн. - 2017. - 13, № 3. C. $184-190$.

10. Metabolic syndrome in polycystic ovary syndrome: a systematic review, meta-analysis and meta-regression / S. Lim, N. Kakoly, J. Tan // Obes. Rev. - 2018. - 20. P. 339-352.

11. Impaired glucose tolerance, but not impaired fasting glucose, is associated with increased levels of coronary heart disease risk factors / D. Blake, J. Meigs, D. Muller [et al.] // Diabetes. - 2004. - 53 (8). - P. 20952100.

12. $\beta$-Cell function in subjects spanning the range from normal glucose tolerance to overt diabetes: a new analysis / E. Ferrannini, A. Gastaldelli, Y. Miyazaki [et al.] // J. Clin. Endocrinol. Metab. - 2005. - 90. P. 493-500.

13. Ginsberg H. The obesity, metabolic syndrome, and type 2 diabetes mellitus pandemic: Part I. Increased cardiovascular disease risk and the importance of atherogenic dyslipidemia in persons with the metabolic syndrome and type 2 diabetes mellitus / H. Ginsberg, P. MacCallum // J. Cardiometab. Syndr. -2009. -4 (2). P. 113-119. 


\section{REFERENCES}

1. Gach, O., Husseini,Z., \& Lancellotti, P. (2018). Acute coronary syndrome. Rev. Med. Liege, 73 (5-6), 243-250.

2. (2012). ESC Guidelines for the management of acute myocardial infarction in patients presenting with ST-segment elevation: The Task Force on the management of ST-segment elevation acute myocardial infarction of the European Society of Cardiology (ESC). European Heart Journal, 33 (20), 2569-2619.

3. Lovic, M., \& Djordjevic, D. (2018). Tasic impact of metabolic syndrome on clinical severity and long-term prognosis in patients with myocardial infarction with STsegment elevation. Hellenic Journal of Cardiology, 59 (4), 226-231

4. Kelli, H., Kassas, I., Lattouf, O.(2015) Cardio metabolic syndrome: A global epidemic. J. Diabetes Metab., 6, 263-275.

5. Ogurtsova, K., Fernandes, J., \& Huang, Y. (2017). IDF Diabetes Atlas: global estimates for the prevalence of diabetes for 2015 and 2040. Diabetes Research and Clinical Practice, 128, 40-50. DOI: 10.1016/j.diabres.2017.03.024.

6. Christopher, J., \& Prentki, M. (2019). Insulin resistance and insulin hypersecretion in the metabolic syndrome and type 2 diabetes: Time for a conceptual framework shift. SAGE Jornal, 16 (2), 118-127. Retrieved from: https://doi.org/10.1177/1479164119827611

7. Sperling, L., Mechanick, J., \& Neeland, I. (2015). The cardiometabolic health alliance: working toward a new care model for the metabolic syndrome. J. Am. Coll. Cardiol., 66, 1050-1067.

8. Khobzey, M.K., Sirenko, Yu.M., \& Stepanenko, A.V. (2014). Nakaz MOZ Ukrainy № 455 vid 02.07.2014. Unifikovanyi klinichnyi protokol ekstrenoi, pervynnoi, vtoryn- noi (spetsializovanoi) ta tretynnoi (vysokospetsializovanoi) medychnoi dopomohy ta medychnoi reabilitatsii khvorykh na hostryi koronarnyi syndrom z elevatsiieiu sehmenta ST [Ministry of Health of Ukraine Order No. 455 dated 2 July 2014. Unified clinical protocol of emergency, primary, secondary (specialized) and tertiary (highly specialized) medical care and medical rehabilitation of patients with acute coronary syndrome with ST segment elevation]. [in Ukrainian].

9. Kaminskyi, O.V. (2017). Ofitsiini kryterii diahnostyky tsukrovoho diabetu, normohlikemiia i samokontrol hlikemii [Official criteria for the diagnosis of diabetes, normoglycemia and glycemic self-control]. Mizhnarodnyi endokrynolohichnyi zhurnal - International Journal of Endocrinology, 13 (3), 184-190 [in Ukrainian].

10. Lim, S., Kakoly, N., \& Tan, J. (2018). Metabolic syndrome in polycystic ovary syndrome: a systematic review, meta-analysis and meta-regression. Obes. Rev., 20, 339-352.

11. Blake, D., Meigs, J., \& Muller, D. (2004). Impaired glucose tolerance, but not impaired fasting glucose, is associated with increased levels of coronary heart disease risk factors. Diabetes, 53 (8), 2095-2100.

12. Ferrannini, E., Gastaldelli, A., \& Miyazaki, Y. (2005). $\beta$-Cell function in subjects spanning the range from normal glucose tolerance to overt diabetes: a new analysis. J. Clin. Endocrinol. Metab., 90, 493-500.

13. Ginsberg, H., \& MacCallum, P. (2009). The obesity, metabolic syndrome, and type 2 diabetes mellitus pandemic: Part I. Increased cardiovascular disease risk and the importance of atherogenic dyslipidemia in persons with the metabolic syndrome and type 2 diabetes mellitus. J. Cardiometab. Syndr., 4 (2), 113-119.

\section{HORBACHEVSKY TERNOPIL NATIONAL MEDICAL UNIVERSITY}

M. I. Shved, I. O. Yastremska

\section{FEATURES OF DISORDERS OF HYDROCARBON AND LIPID METABOLISM IN PATIENTS WITH ACUTE MYOCARDIAL INFARCTION WITH NORMAL AND OVERWEIGHT}

\section{Summary}

Introduction. In terms of prevalence and adverse effects, acute myocardial infarction (MI) remains one of the most pressing problems in cardiology for many years.

The aim of the study - comparative analysis of indicators of metabolism of hydrocarbon and lipid metabolism in patients with MI with normal and elevated body mass index and persons with metabolic syndrome.

Research Methods. The study included 77 men with acute ST-segment elevation myocardial infarction. All patients had body weight $(\mathrm{kg})$, height $(\mathrm{m})$, body mass index - BMI $\left(\mathrm{kg} / \mathrm{m}^{2}\right)$, waist circumference (WC) and hip circumference (HC), WC/HC ratio. By BMI, patients were divided into three groups: normal body weight $\left(18.5<B M l<24.9 \mathrm{~kg} / \mathrm{m}^{2}\right)$ - group 1 ( $\left.n=23\right) ;$ overweight $\left(25<B M I<29.9 \mathrm{~kg} / \mathrm{m}^{2}\right)-$ group 2 ( $\left.n=33\right)$, obesity $\left(B M />30 \mathrm{~kg} / \mathrm{m}^{2}\right)$ - group $3(n=21)$. The biochemical study determined the levels of cardiac troponins I and $T$, CF fraction of creatine phosphokinase (CPK-MB), blood lipid spectrum, glycemia and insulin concentration at baseline, on an empty stomach after 8 hours of fasting and for 12 days. At the same time, patients were also determined postprandial blood glucose levels, and if necessary, performed a test for tolerance to carbohydrates according to conventional methods. Statistical processing of the obtained results was performed using the statistical software package "Statistica 10.0" and the program "Microsoft Exel-2013". 
Results and Discussion. At baseline, in most patients of all study groups, the indicators of WC and WC/HC exceeded the upper limit of the gender norm: in group 1 - in $69.5 \%$ ( $n=16)$, in group $2-$ in $81.8 \%$ ( $n=27)$, in group 3 - in $85.7 \%(n=18)$ patients $(p<0.05)$, which indicates dysmetabolic disorders in the body not only in patients with overweight and obesity, but also in patients with normal body weight. At the same time, these patients were diagnosed with hyperglycemia, hyperinsulinemia and atherogenic dyslipoproteinemia.

Conclusion. The development of insulin resistance and metabolic syndrome in patients with MI is accompanied by significant disorders of carbohydrate and lipid metabolism, manifested by hyperglycemia, hyperinsulinemia and atherogenic dyslipidemia in acute and subacute periods of the disease in patients with visceral obesity.

KEY WORDS: myocardial infarction; overweight; obesity; insulin resistance; visceral fat; carbohydrate metabolism, fat metabolism.

Отримано 17.09.21

Адреса для листування: І. О. Ястремська, Тернопільський національний медичний університет імені І. Я. Горбачевського мО3 України, майдан Волі, 1, Тернопіль, 46001, Україна, e-mail: yastremskaio@tdmu.edu.ua. 